\title{
Theoretical substantiation of parameters of the planetary fruit separator
}

\author{
Sergey V. Belousov ${ }^{1, *}$, Sergey Yu. Onikienko ${ }^{1}$, and Darya M. Klinova ${ }^{1}$ \\ ${ }^{1}$ Federal State Budgetary Educational Institution of Higher Education «Kuban State Agrarian \\ University named after I.T. Trubilin»
}

\begin{abstract}
The work is devoted to the theoretical substantiation of the parameters of the planetary fruit separator of nightshade vegetables both in direct and reusable ways. The article has a theoretical research character expressed in the fact that the analysis of the method of harvesting nightshade vegetables is theoretically given. There was determined the main theoretical trend of equipment development and advancing its design to improve the quality of its work. There were given the type of the proposed design, its theoretical description and the flow of technological process. As a result of the work done, the design of the device for reusable nightshade vegetables harvesting with proposed working bodies is presented. The conclusions present the main results achieved so far.
\end{abstract}

Planetary multi-rolling apparatus for reusable separation of nightshade vegetables fruits consists of two drums placed at an angle $\alpha$ to the horizon, each of which has several (n) rollers of small diameter (Figure 1). The drums rotate in different directions from bottom to top, towards the fruit conveyors, which are located on both sides of the fruit separator. Rollers, located on the perimeter of the drums, also rotate in different directions, coinciding with the direction of stem rolling - down to the base of the stem.

The operation gap in the fruit-separating apparatus is the gap between the rollers of the drums in the area passing through the axes of the drums' rotation.

To determine the length of fruit-separating drums we will set the initial conditions, namely the branches of the plant raised by stem lifts are introduced into the operation gap of the drums at point A (Figure 1) and must be completely taken from the fruit separator at the point B. We denote $\mathrm{H}$ (Figure 1) as a height of the plant's bush; h as a distance from the soil surface to the level of plants' entry into the operation gap between the drums; this argument is defined by technological features of drums and we take it as equal to the radius of drums at the entrance to the fruit separator: $h=R_{\delta} L$ - length of drums of the fruit separator; A - the angle of inclination of the drum's axis to the horizon.

From $\triangle \mathrm{ABC}$ follows

$$
\frac{H-h}{L}=\sin \alpha
$$

\footnotetext{
* Corresponding author: sergey belousov 87@mail.ru
} 
Whence

$$
\mathrm{L}=\frac{\mathrm{H}-\mathrm{h}}{\operatorname{sinck} \mathrm{ck}}
$$

In order to eliminate the loss of fruit from rolling on the rollers, the angle $\alpha$ should be less than the angle of rolling the fruit on the rolls $\alpha_{\mathrm{c \kappa}}$, that is

$$
\alpha \leq \alpha_{\mathrm{ck}}
$$

Considering that $\mathrm{h}=\mathrm{R}_{\delta}$, in final type has

$$
\mathrm{L}=\frac{\mathrm{H}-\mathrm{R} 8}{\sin \varepsilon_{\mathrm{ck}}}
$$

Thus, the length of the drums depends on both the physical and mechanical properties dimensional characteristics of plants and the angle of fruit rolling, and on the design parameters of the fruit separator. Higher plants require an increase in the length of the drums or an increase in the angle of $\alpha$.

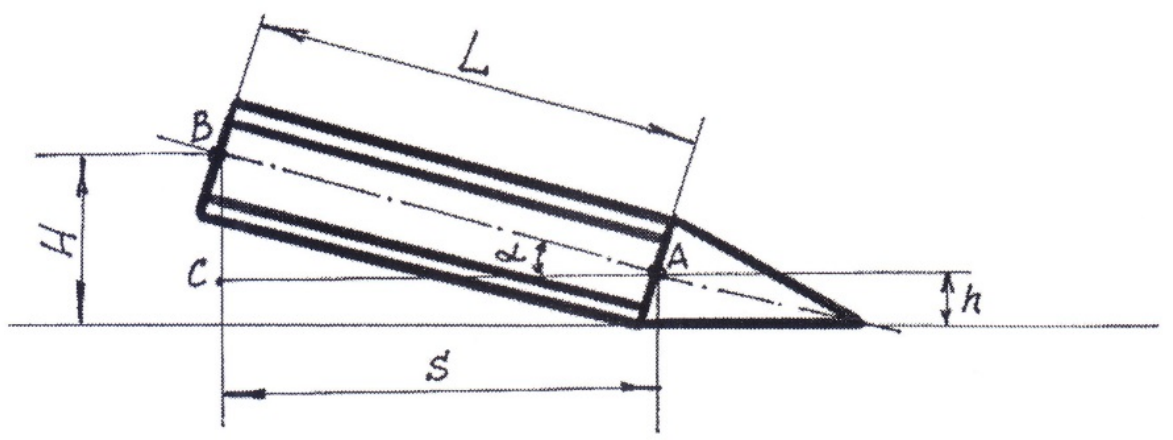

Fig. 1. To determination of the length of the drum

Also, an important factor in the harvesting process is the diameter of the fruit separator drum. Considering the kinematics of the planetary drum, we note that at any connection of the centers of the cylinders by straight lines we get a regular polygon which number of sides is determined by the number of cylinders and the angle between the center of the drum $\mathrm{O}_{6}$ and the centers of circumference of the adjacent rollers $\mathrm{O}_{\mathrm{B} 1}$ and $\mathrm{O}_{\mathrm{B} 2}$ by the angle $\varepsilon$ is $360 / n$ (Figure 2).

The side of the polygon $\mathrm{O}_{\mathrm{B} 1} \mathrm{O}_{\mathrm{B} 2}$ (Figure 2) can be expressed as

$$
a=2 R_{B}+Z,
$$

where $\mathrm{R}_{\mathrm{B}}$ - radius of roller;

$\mathrm{Z}$ - gap between rollers. 


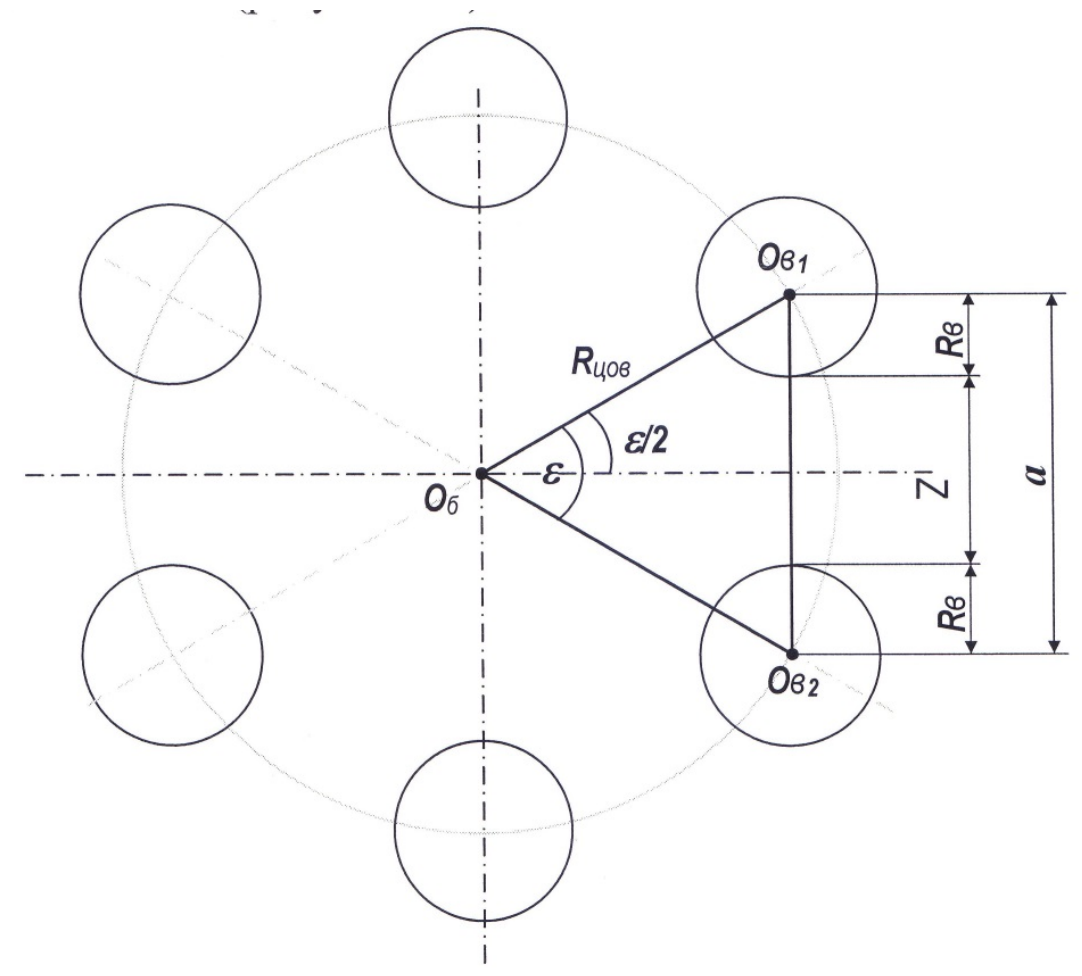

Fig. 2. To determination of number of rollers

The gap between the rollers should exclude the ingress of small fruits and parts of the plant into the drum.

The radius of the rollers is comparable to the size of the average fruit (choose 20-25 $\mathrm{mm}$ ). Defining "a" - for the selected number of rollers, define the perimeter $\mathrm{P}$ of the polygon, and the radius of the circle on the centers of the rollers from it.

$$
\mathrm{P}=\mathrm{n} \cdot \mathrm{a}=2 \mathrm{n} \cdot \mathrm{R}_{\text {цов }}{ }^{*} \sin \frac{\bar{s}}{2},
$$

where $\mathrm{R}_{\text {цов }}$ - radius of roller center circumference.

Whence

$$
\mathrm{R}_{\text {цов }}=\frac{\text { nब }}{2 n \sin ^{2} s_{2}}=\frac{a}{2 \sin s_{2}}(3)
$$

In this case the diameter of the drum will be equal to

$$
Д_{6}=2\left(\mathrm{R}_{\text {пов }}+\mathrm{R}_{\text {в }}\right) \text {, }
$$

The relationship between the number of rollers and the diameter of the drum for $\mathrm{Z}=25$ $\mathrm{MM}, \mathrm{R}_{\mathrm{B}}=20$ and $25 \mathrm{~mm}$ was shown in Figure 3.

The dependence of $\mathrm{D}_{6}$ on $\mathrm{n}$ is a weakly expressed sinusoidal dependence, which can practically be considered close to proportional.

Increasing the number of rollers and their radius leads to an increase in the diameter of the drum. 


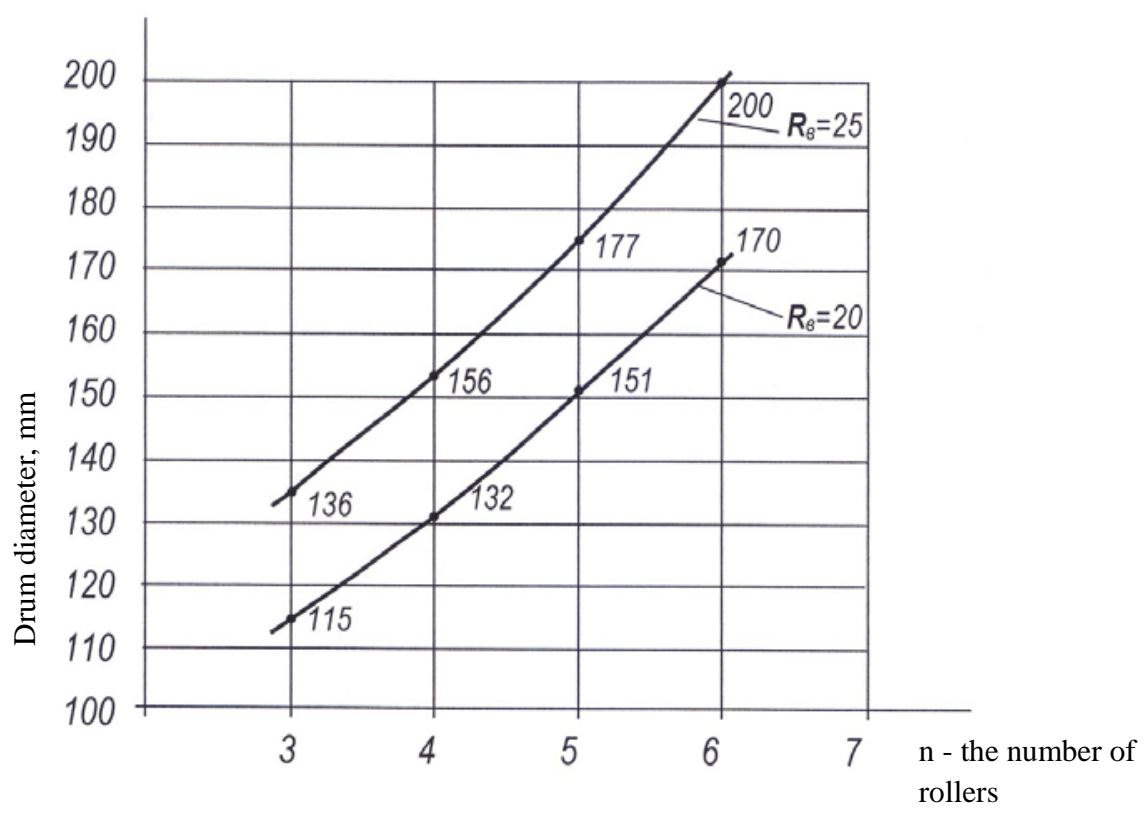

Fig. 3. Dependence $\mathrm{D}_{6}$ on the number of rollers $\mathrm{n}$.

In the process of planetary fruit separator the essential condition is not to tighten the fruit of a given size in the gap between the rollers of adjacent drums.

To ensure this, it is necessary that the tightening angle is greater than twice the angle of friction of the fruit on the surface of the rollers.

$$
\alpha_{3 a x}>2 \varphi
$$

where $\alpha_{\text {зат }}$ - tightening angle;

$\varphi$ - angle of friction and slide.

The angle of tightening $\alpha_{\text {зат }}$ is determined (Figure 4) by intersection of perpendiculars recovered at the contact points to line radii which is common for rollers and the fruit.

Express the angle $\alpha_{\text {зат }}$ from the quadrangle of $\mathrm{AO}_{\mathrm{n}} \mathrm{BC}$ (Figure 4).

$\alpha_{\text {зат }}+90+90+\mu=360^{\circ}$

$\alpha_{\text {зат }}+\mu=180^{\circ}$

$\alpha_{\text {зат }}=180^{\circ}-\mu$. 


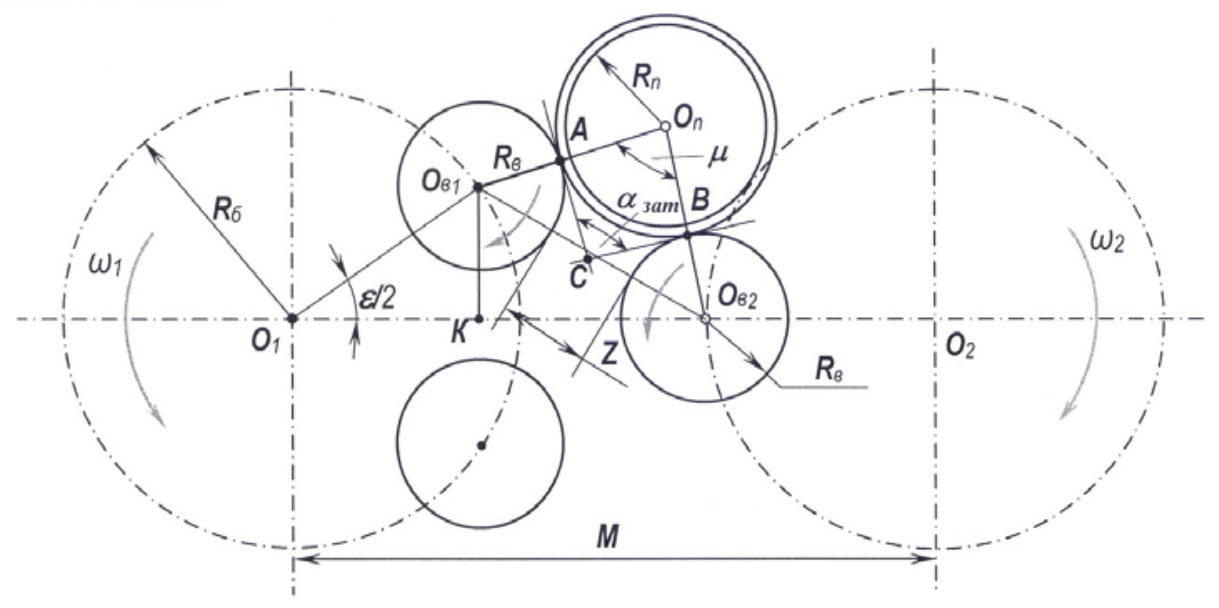

Fig. 4. Determination of the angle of tightening $\alpha_{3 a r}$.

The angle ц can be determined from $\Delta \mathrm{O}_{\mathrm{B} 1} \mathrm{O}_{n} \mathrm{O}_{\mathrm{B} 2}$. So, $\mathrm{O}_{\mathrm{B} 1} \mathrm{O}_{n}$ и $\mathrm{O}_{\mathrm{n}} \mathrm{O}_{\mathrm{B} 2}$ are equal to $\mathrm{R}_{\mathrm{B}}+$ $R_{n}$, где $R_{B} u R_{n}$ respectively radii of the drum's rollers and fruit radius, and the side $O_{в 1} O_{в 2}$ is equal

$$
\mathrm{O}_{\mathrm{B} 1} \mathrm{O}_{\mathrm{B} 2}=2 \mathrm{R}_{\mathrm{B}}+\mathrm{Z},
$$

where Z- gap between rollers of the adjacent drums.

By the cosine theorem we have

$$
\left(2 R_{B}+Z\right)^{2}=\left(R_{B}+R_{n}\right)^{2}+\left(R_{B}+R_{n}\right)^{2}-2\left(R_{B}+R_{n}\right)\left(R_{B}+R_{n}\right) \cos \mu
$$

or

$$
\begin{gathered}
\left(2 \mathrm{R}_{\mathrm{B}}+\mathrm{Z}\right)^{2}=2\left(\mathrm{R}_{\mathrm{B}}+\mathrm{R}_{\mathrm{n}}\right)^{2}-2\left(\mathrm{R}_{\mathrm{B}}+\mathrm{R}_{\mathrm{n}}\right)^{2} \cos \mu \\
2\left(\mathrm{R}_{\mathrm{B}}+\mathrm{R}_{\mathrm{n}}\right)^{2} \cos \mu=2\left(\mathrm{R}_{\mathrm{B}}+\mathrm{R}_{\mathrm{n}}\right)^{2}-\left(2 \mathrm{R}_{\mathrm{B}}+\mathrm{Z}\right)^{2} \\
\cos \mu=\frac{2\left(R_{\mathrm{B}}+R_{\mathrm{M}}\right)^{\mathrm{N}}-\left(2 R_{\mathrm{M}}+Z\right)^{\mathrm{D}}}{2\left(R_{\mathrm{B}}+R_{\mathrm{M}}\right)^{2}} \\
\mu=\arccos \frac{2\left(R_{\mathrm{B}}+R_{\mathrm{M}}\right)^{\mathrm{D}}-\left(2 R_{\mathrm{B}}+Z\right)^{\mathrm{N}}}{2\left(R_{\mathrm{B}}+R_{\mathrm{M}}\right)^{\mathrm{N}}}
\end{gathered}
$$

and consequently

$$
\alpha_{\text {зат }}=180^{\circ}-\arccos \frac{2\left(R_{\mathrm{R}}+R_{\mathrm{R}}\right)^{\mathrm{D}}-\left(2 R_{\mathrm{B}}+Z\right)^{\mathrm{T}}}{2\left(R_{\mathrm{R}}+R_{\mathrm{M}}\right)^{\mathrm{I}}}
$$

Determine the gap between the rollers.

In the expression (6) parameters are $R_{B}$ and $R_{n}$, the latter must be equal to the minimum value of the radius of harvested fruit, i.e. $R_{B}$ and $R_{n}$. This is justified by the fact that at the same values $R_{B}$ and $Z$ the decreasing the fruit size leads to a reduction of the tightening angle $-\alpha_{\text {зат }}$, that is, in this case increases the possibility of fruit tightening between rollers of adjacent rollers (Figure 5).

$$
R_{n}^{s}<R_{n}
$$




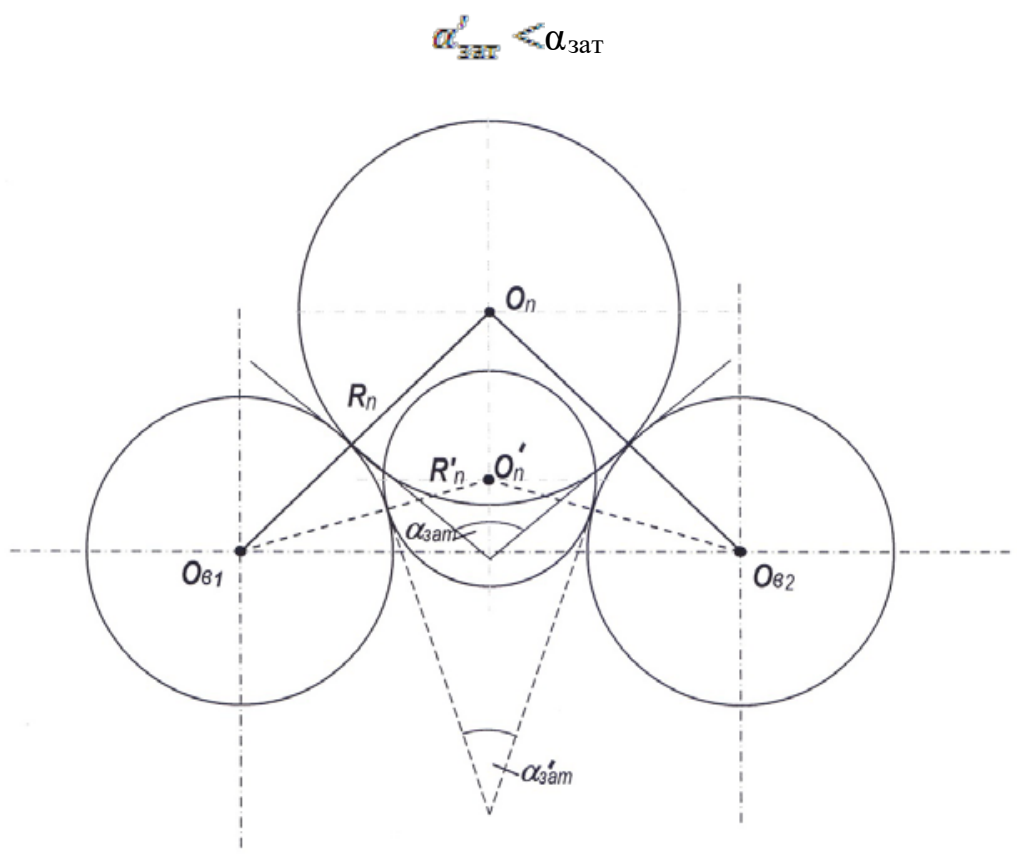

Fig. 5.To justification of choice $R_{n}$

As for the choice of the gap $\mathrm{Z}$, provided $2 R_{\mathrm{mI}}^{s}=\mathrm{Z}$ или $2 R_{\mathrm{mI}}<\mathrm{Z}$ small fruits will pass through the gap between the rollers of adjacent drums and after further growth to be removed at the subsequent passage of the harvester. This is the essence of reusable cleaning.

Consider the case when the rollers of adjacent drums are installed without displacement relative to each other. In this case, the minimum gap between the rollers of adjacent drums will be the case when the centers of the rollers will lie on the line $\mathrm{O}_{1} \mathrm{O}_{2}$, connecting the centers of the drums, and the gap will be equal to $\mathrm{O}_{1} \mathrm{O}_{2}-2 R_{\sigma}$, where $0_{1} 0_{2}$ - center-tocenter distance between drums, $\mathrm{aR}_{\sigma}$ is the radius of the drum. The size of the gap between the drums in this case is determined by the diameter of the main stem of the plant's bush.

However, such an arrangement of rollers of adjacent drums of the fruit separator eliminates the oscillation of stalks required for fruit separation, this dramatically increases the damage and fruit losses on the ground.

To ensure the oscillation of the stem, the rollers of adjacent drums are shifted relative to each other at an angle equal to half the angle between adjacent rollers on the drums. In this case, the minimum distance between the centers of the circles of the rollers involved in the process of rolling the stem and its oscillations, and therefore the gap between them increases somewhat against the original case, but will be the same at the extreme positions of the stem during its oscillations.

The stem takes the extreme position when the center of the circle of one of the rollers, regardless on which drums is located on the $\mathrm{O}_{1} \mathrm{O}_{2}$ line connecting the centers of the drums' circles. In the intermediate ones between the extreme positions of the stem, the gap between the rollers of the drums involved in the process of stem rolling does not change.

This is because moving in the zone of oscillation of the stem in circles at identical angular velocities of the drums when turning by the same angle the approximation of one of the rollers to other drum, is compensated removing the roller of other drum. 
Therefore, to determine the gap between the rollers of adjacent drums, it is sufficient to determine it for the position when the center of the circle of one of the rollers of any drum is on the line connecting the centers of the drums $\mathrm{O}_{1} \mathrm{O}_{2}$.

Let's consider $\Delta \mathrm{O}_{\mathrm{B} 1} \mathrm{KO}_{\mathrm{B} 2}$, where as $\mathrm{O}_{\mathrm{B} 1} \mathrm{O}_{\mathrm{B} 2}=2 \mathrm{R}_{\sigma}+\mathrm{Z}$.

The side $\mathrm{O}_{\mathrm{B} 1} \mathrm{~K}$ will be defined from $\Delta \mathrm{O}_{1} \mathrm{O}_{\mathrm{B} 1} \mathrm{~K}$,

Whence

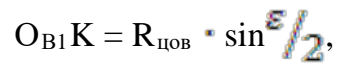

And the side $\mathrm{KO}_{\mathrm{B} 2}$ will be defined as a difference of center-to-center distance $\mathrm{O}_{1} \mathrm{O}_{2}(\mathrm{M})$ and sum of segments $\mathrm{O}_{2} \mathrm{O}_{\text {В } 2}$ and $\mathrm{R}_{\text {цов }}$ and $\mathrm{O}_{1} \mathrm{~K}=\boldsymbol{R}_{\text {цов }}{ }^{*} \cos ^{\varepsilon} / 2$.

$$
\mathrm{KO}_{\text {В2 }}=\mathrm{M}-\mathrm{R}_{\text {цов }}-\mathrm{R}_{\text {цов }}{ }^{\circ} \cos ^{\varepsilon} / 2=\mathrm{M}-\mathrm{R}_{\text {цов }}\left(1+\cos ^{\varepsilon} / 2\right)
$$

After that we can put down

$$
2\left(\mathrm{R}_{\mathrm{B}}+\mathrm{R}_{\mathrm{n}}\right)^{2}=\left(\mathrm{R}_{\text {цов }}{ }^{*} \sin ^{\varepsilon} / 2\right)^{2}+\left[\mathrm{M}-\mathrm{R}_{\text {цов }}\left(1+\cos ^{\varepsilon} / 2\right)\right]^{2}
$$

transforming

$$
\begin{gathered}
4 R_{\mathrm{E}}^{2}+4 \mathrm{R}_{\mathrm{B}} \mathrm{Z}+\mathrm{Z}^{2}=\left(\mathrm{R}_{\text {Lов }}{ }^{*} \sin ^{\varepsilon} / 2\right)^{2}+\left[\mathrm{M}-\mathrm{R}_{\text {цов }}\left(1+\cos ^{\varepsilon} / 2\right)\right]^{2} \\
\mathrm{Z}^{2}+4 \mathrm{R}_{\mathrm{B}}{ }^{*} \mathrm{Z}+4 R_{\mathrm{E}}^{2}=\left(\mathrm{R}_{\text {цов }}{ }^{*} \sin ^{\varepsilon} / 2\right)^{2}+\left[\mathrm{M}-\mathrm{R}_{\text {цов }}\left(1+\cos ^{\varepsilon} / 2\right)\right]^{2}
\end{gathered}
$$

and meaning

$$
\begin{gathered}
4 \mathrm{R}_{\text {в }}=\rho \\
4 R_{\mathrm{E}}^{2}-\left(\mathrm{R}_{\text {цов }}{ }^{*} \sin ^{\varepsilon} / 2\right)^{2}+\left[\mathrm{M}-\mathrm{R}_{\text {цов }}\left(1+\cos ^{\varepsilon} / 2\right)\right]^{2}=\mathrm{g}
\end{gathered}
$$

we come to the above equation

$$
\mathrm{Z}^{2}+\mathrm{pZ}+\mathrm{g}=0
$$

roots of which

$$
Z_{1,2}=-\frac{\rho}{2} \pm \sqrt{\frac{\rho^{3}}{4}-g(7)}
$$

In expression (7), it is necessary to take only positive $\mathrm{Z}$ values, since negative values have no sense.

At the accepted parameters of the drum $R_{в}, R_{\text {цов }}, Z_{\sigma}$, the value of the gap between the rollers of the lower drums involved in the process of rolling the stems will depend only on the value of the inter-center distance of the drums.

To determine this distance, and therefore the range of permissible values $\mathrm{Z}$, we make the following assumptions - the gap between the adjacent rollers of one drum and the opposite roller of the other drum should be equal to the average diameter of the rolled stem.

Figure 6 shows the position of the stem at the time of its contact with the rollers of adjacent drums.

Inter-center distance $\mathrm{O}_{1} \mathrm{O}_{2}$ is a sum of segments $\rho^{\prime}, Z_{\text {в }}, R_{B}, R_{\text {цов }}$, that is 


$$
\mathrm{O}_{1} \mathrm{O}_{2}=\rho^{\prime}+\mathrm{Z}_{\text {в }}+\mathrm{R}_{\text {в }}+\mathrm{R}_{\text {цов }}
$$

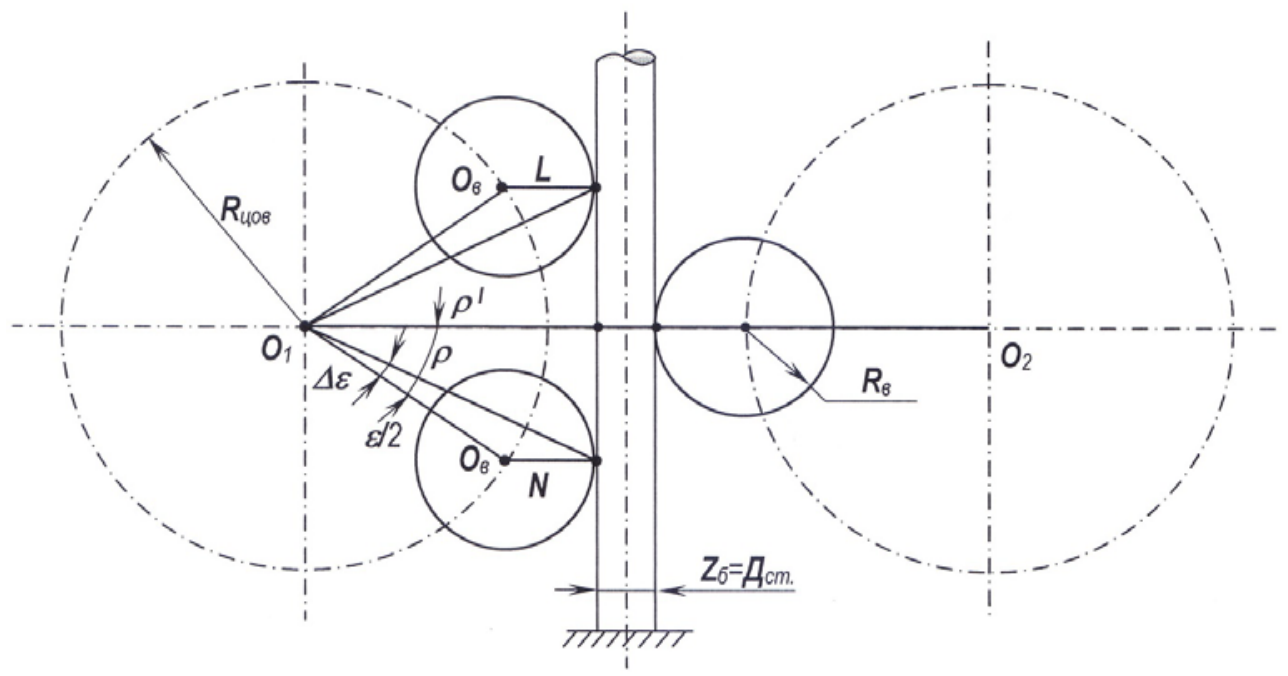

Fig. 6. To determination of the inter-center distance between drums.

Here the unknown is $\rho^{\prime}$.

The stems are in contact with the rollers at the points $\mathrm{L}$ and $\mathrm{N}$. Let us denote the distance from the center of a circle of drums to those points in terms of $\rho$ and the projection of this value on the line $\mathrm{O}_{1} \mathrm{O}_{2}$ via $\rho$ ', which should be determined.

From $\Delta \mathrm{O}_{1} \mathrm{O}_{\mathrm{B}} \mathrm{N}$ by the sine theorem

$$
\rho^{2}=R_{\text {प्रण }}^{2}+R_{\mathrm{E}}^{2}-2 \mathrm{R}_{\text {प्रण }} \cdot \mathrm{R}_{\mathrm{B}} \cdot \cos (180-\varepsilon / 2)
$$

or

$$
\rho=R_{\text {L्ष }}^{2}+R_{\mathrm{B}}^{2}+2 \mathrm{R}_{\text {цов }} \cdot \mathrm{R}_{\mathrm{B}} \cdot \cos ^{\varepsilon} / 2
$$

whence

$$
\rho=\sqrt{R_{\mathrm{LOE}}^{2}+R_{\mathrm{E}}^{2}+2 R_{\mathrm{LOE}} \cdot R B \cdot \cos ^{\varepsilon} / 2}
$$

and projection $\rho$ in direction $\mathrm{O}_{1} \mathrm{O}_{2}$

$$
\rho^{\prime}=\sqrt{R_{\text {LOE }}^{2}+R_{\mathrm{E}}^{2}+2 R_{\text {पूर }} \cdot R_{\mathrm{E}} \cdot \cos ^{\varepsilon} / 2} \cdot \cos \left(\varepsilon^{\varepsilon} / 2-\Delta \varphi\right)
$$

In the expression (3.46), the angle $\Delta \varphi$ remains unknown, which can be determined by the sine theorem

$$
\frac{R_{\mathrm{E}}}{\sin \Delta \varepsilon}=\frac{\rho}{\sin (180-\varepsilon / 2)}
$$




$$
\frac{\mathrm{R}_{\mathrm{E}}}{\sin \Delta \varepsilon}=\frac{\rho}{\sin ^{\varepsilon} / 2}
$$

whence

$$
\Delta \varepsilon=\arcsin \frac{R_{\mathbb{B}} \times \sin s \beta_{2}}{\rho}
$$

For $\mathrm{R}_{\mathrm{B}}=25 \mathrm{MM} ; \mathrm{R}_{\text {цов }}=75 \mathrm{MM} \mathrm{И} \varepsilon=60^{\circ}$ the calculations give the following values:

$\rho=97,5 \mathrm{~mm} ; \Delta \varepsilon=7,36^{\circ} ; \rho^{\prime}-90 \mathrm{~mm}$.

In this case, with a stem diameter of $10-14 \mathrm{~mm}$, the gap $\mathrm{Z}_{\sigma}$ will be equal to this value, and the center-to-center distance between the drums will be

$\mathrm{OO}_{1}=90+10+25+75=200 \mathrm{~mm}$.

$\mathrm{OO}_{1}=90+14+25+75=204 \mathrm{~mm}$.

So, the interval of admissible values $\mathrm{O}_{1} \mathrm{O}_{2}$ is $200-205 \mathrm{~mm}$.

Dependencies between $\mathrm{O}_{1} \mathrm{O}_{2}$ and $\mathrm{Z}$ were shown in Figure 9.

Table 1. Gap between the rollers at different inter-center distance of the drums (mm).

\begin{tabular}{|c|c|c|c|c|c|}
\hline $\begin{array}{c}\text { Inter-center distance of } \\
\text { drums } \mathrm{O}_{1} \mathrm{O}_{2}\end{array}$ & 200 & 205 & 210 & 215 & 220 \\
\hline Gap between rollers & 21,1 & 25,1 & 29,5 & 33,9 & 38,4 \\
\hline
\end{tabular}

From the data of Table 1, it follows that an increase in $\mathrm{O}_{1} \mathrm{O}_{2}$ leads to an increase in the gap between the rollers of the drums in the zone of contact with the stem according to the dependence close to directly proportional.

For the range of permissible values $\mathrm{Z}(200-250 \mathrm{~mm})$ we determine the angle of tightening by the expression (6) for fruits of different diameters. Take into consideration that $\cos (-\alpha)=+\cos (\alpha)$. It excludes changing the minus sign to the plus sign in the expression (6). The calculations are done for the unit which radius of rollers are $\mathrm{RB}_{\mathrm{B}}=25$ $\mathrm{mm}$; at $\mathrm{Z}=21, \mathrm{l} ; \mathrm{Z}=25, \mathrm{l}$ and the radius of the fruit $\mathrm{Rn}=10,15,20,25$ and $30 \mathrm{~mm}$. The results are shown in Table 22.

Table 2. Angles of fruit tightening at their different radii.

\begin{tabular}{|l|l|l|}
\hline \multirow{2}{*}{ Radius of fruit, (mm) } & \multicolumn{2}{|c|}{ Angle of tightening (degree) } \\
\cline { 2 - 3 } & At Z=21,1 mm & At Z=25,1 mm \\
\hline 10 & 137,3 & 180 \\
\hline 15 & 109,15 & 124,6 \\
\hline 20 & 92,8 & 103,9 \\
\hline 25 & 98,6 & 92,3 \\
\hline 30 & 107,3 & 199,8 \\
\hline
\end{tabular}

The graphical interpretation of the data is shown in Figure 7.

The minimum value of the tightening angle $\alpha_{\text {зат }}$ will be when the angle $\mu$ reaches the maximum value, and it is possible when $\cos \mu=0$, and the angle itself will be $90^{\circ}$. In this case, the minimum value will be $\alpha_{3}=180-90=90^{\circ} \cos \mu$, in its turn, will be equal zero at $\mathrm{R}_{\mathrm{n}}=\mathrm{Z}$. It is determined in Figure 7. 


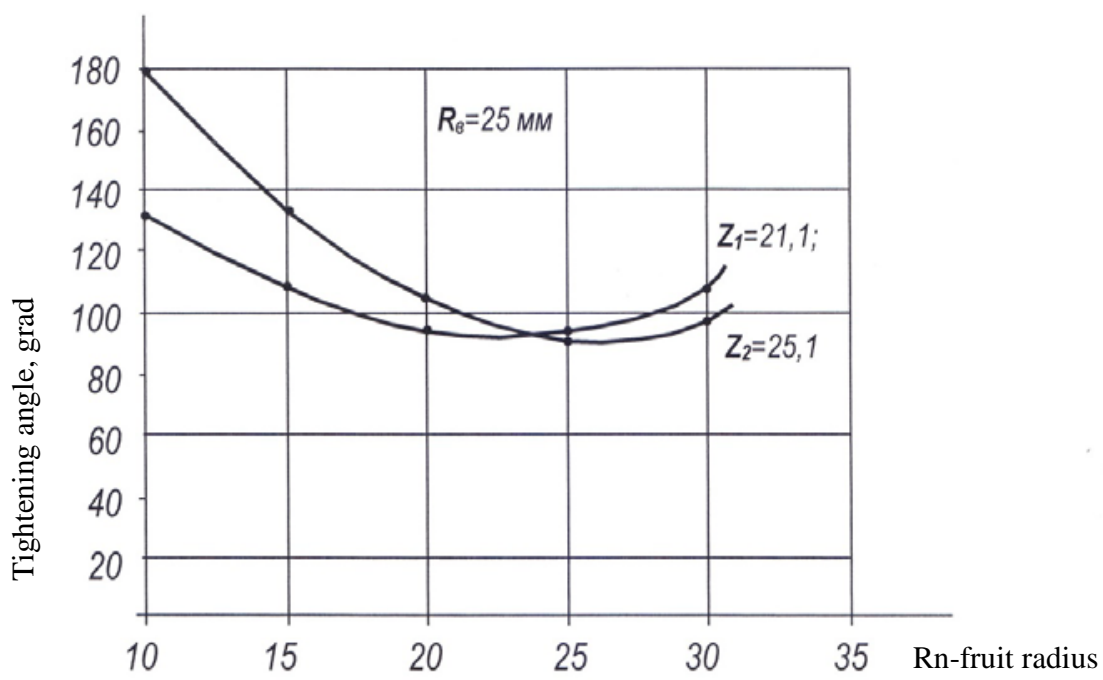

Fig. 7. Dependence of the tightening angle on the size of the fruit.

Thus, fruit with a diameter of $Д_{\Pi}=2 R_{n}<Z$ will freely pass into the gaps between the drums for re-harvesting, and other larger ones, will not be delayed between the drums, provided $\alpha_{3 \text { aт }}>2 \varphi$ or $\varphi<45^{\circ}$.

Thus, the planetary fruit separator with following parameters: diameter of 170-200 mm; number of cylinders - 6 PCs; roller diameter - 40-50 mm, center-to-center distance of 200$205 \mathrm{~mm}$, will be to separate the fruits of a radius larger than $25 \mathrm{~mm}$. Fruit of smaller radius pass through the device and continue their vegetative growth, under the condition that the coefficient of fruit friction on rollers will not be greater than one.

\section{References}

1. Trubilin E.I. Results of experimental studies determining the degree of traction resistance of the plowshare in the treatment of heavy soils / Trubilin E.I., Belousov S.V., Lepshina A.I. // Multidisciplinary Network Electronic Scientific Journal of Kuban State Agrarian University. -2014. -No. 103.-P. 673-686.

2. Trubilin E.I. Economic efficiency of the dump cultivation of soil developed by a combined plowshoe / Trubilin E.I., Belousov S.V., Lepshina A.I. // Multidisciplinary network electronic scientific journal of Kuban State Agrarian University. -2014. -No. 103.-P. 654-672.

3. Trubilin E.I. The main soil cultivation with the formation of turnover in modern operation conditions and devices for its implementation / Trubilin E.I., Belousov S.V., Lepshina A.I. // Multidisciplinary network electronic scientific journal of Kuban State Agrarian University. -2014. - No. 104.- P. 1902-1922.

4. Belousov S.V. Communication of science and technology in the field of development of machines for the basic tillage of the soil with the circulation of the bed / Belousov S.V. // Multidisciplinary network electronic scientific journal of Kuban State Agrarian University. -2015. No. 109.- P. 468-486.

5. Belousov S.V. Modern technologies of soil cultivation / Belousov S.V. // Scientific Provision of Agro-Industrial Complex. -2012. - P. 3-4. 
6. Parkhomenko G.G. Improvement of working organs for tillage / Parkhomenko G.G., Bozhko I.V., Semenikhina Y.A., Pantyukhov I.V., Drozdov S.V., Gromakov A.V., Kambulov S.I., Belousov S.V. // State and prospects of the development of agricultural machinery. Collection of scientific works of the $9^{\text {th }}$ International scientific and practical conference within the framework of the $19^{\text {th }}$ International agro-industrial exhibition "Interagromash-2016". -2016. P. 27-30.

7. Belousov S.V. Development of the construction of a plow for the treatment of heavy soils / Belousov S.V., Trubilin E.I. // Science of the Kuban. -2013. -No 1.-P. 37-40.

8. Belousov S.V. Patent search for structures that provide soil treatment with the turnover of the reservoir. Search method. The proposed technical solution / Belousov S.V. // Multidisciplinary network electronic scientific journal of the Kuban State Agrarian University. -2015. No.109.-P. 416-450.

9. Belousov S.V. Decrease in energy intensity of the process of basic processing of soil with turnover of the bed / Belousov S.V. // Fundamental foundations of modern agrarian technologies and technology. Collection of scientific works of the AllRussian Youth Scientific and Practical Conference.- Tomsk National Polytechnic University. -2015. -P. 280-283.

10. Belousov S.V. Role and prospects of the development of small-scale mechanization in the context of co-temporary engineering / Belousov S.V. / Scientific support of AgroIndustrial Complex. A collection of articles on the materials of the $72^{\text {nd }}$ Scientific and Practical Conference of pre-applicants on the results of research work for 2016 2017.-P. 277-278. 